\title{
Treatment with mesenchymal stem cells for xerostomia: A new paradigm in cell therapy
}

\author{
Soler Rich Robert ${ }^{1}$, Coromina Isern Jordi ${ }^{2}$, Rius Tarruella Joan ${ }^{1 *}$, Zamora Bustamante Jeanneth ${ }^{2}$ and Orozco Delclós Lluís $^{1}$ \\ ${ }^{1}$ Institut de Teràpia Regenerativa Tissular (ITRT), Centro Médico Teknon (Grupo Quirón Salud), Calle Vilana12, 08022 Barcelona, Spain \\ ${ }^{2}$ Centro de Otorrinolaringología, Centro Médico Teknon (Grupo Quirón Salud), Calle Vilana12, 08022 Barcelona, Spain
}

Xerostomia is the term used to define dry mouth due to a deficit of salivary secretion that is generally only perceived when the flow rate is reduced by $40-50 \%$ [1]. Actually, the three main causes of severe xerostomia are: adverse effects of drugs, including chemotherapy, Sjögren syndrome, and radiation therapy for head and neck cancer [2].

Radiation therapy plays an important role in the treatment of neoplasms either as a single modality or in combination with chemotherapy, surgery, or both, but the ionizing radiation can cause alterations in the salivary glands due to its highly sensitive to radiation with destructive effect of acinar cells, atrophy, fibrosis, and the consequent deterioration of salivary gland function [3]. The total average dose range representing the threshold for a significant reduction in salivary flow rate is 26-39 Gray_Gy_ [4]. The dose causing toxicity in $50 \%$ of individuals _TD 50_ is likely to approach 40 Gy [5].

Methods used to reduce the incidence of xerostomia after radiation include advanced radiation techniques_IMRT or proton therapy_, protective agents, and decreased radiation therapy [6,7]. On the other hand, different therapeutic strategies have been developed to improve the function of the salivary gland after radiotherapy $[2,8]$.

Mesenchymal stem cells_MSC_for the treatment of xerostomia including radiation-induced have shown promising results in preclinical studies [9]. The results of a randomized placebo-controlled phase I/ II clinical trial involving 30 patients with xerostomia by radiationinduced, to assess the safety and efficacy of MSC therapy of adipose tissue in have been published [10]. Patients had received radiotherapy for oropharyngeal squamous cell carcinoma _T1-2, N0-2a_. Not adverse events were reported, and the unstimulated salivary flow rate was measured at the first and fourth months after the treatment. The MSC arm has significantly increased by $33 \%$ at first month $(p=0.048)$ and $50 \%$ at fourth month $(\mathrm{p}=0.003)$, but not in the placebo $\operatorname{arm}(\mathrm{p}=0.6)$ and $(\mathrm{p}=0.8)$.

Our research team have experience in the application of MSC in diverse pathologies [11-14] and in collaboration with the Senior Researcher of the cited work_Dr. C. Grønjøj_, had the occasion to treat a patient affected by xerostomia in the context of compassionate use treatment authorized and controlled for the Spanish Medicine Agency using an intraglandular infusion of a 35x10E6 MSC dose in each submaxillary gland. The MSV of the patients, were obtained from bone marrow aspiration, isolated and expanded under Good Manufacturing Practice_GMP_by IBGM_Institute of Biology and Molecular Genetics of Valladolid University, Spain_. The patient had a basal sialometry of $0.05 \mathrm{ml} / \mathrm{min}$ that has pass to $0.12 \mathrm{ml} / \mathrm{min}$ at 3 months. This represents a change of $240 \%$. It is important to mention that a $20 \%$ increase, is considered already to be satisfactory. MRI performed 10 months after treatment shows an increase in the size of the right submaxillary gland _basal passing from $13 \times 6 \times 12 \mathrm{~cm}^{3}$ to $15 \times 8 \times 12 \mathrm{~cm}^{3}$. The left one did not vary in volume. The contrast diffusion changed from 1.33 to 1.55 in the right gland and from 1.36 to 1.55 in the left gland.

All of this has justified and stimulated the design and development of the Phase II clinical trial, not controlled, open-label, prospective, with a single centre and a single group of 10 patients from 18 years to 75 years with xerostomia caused by bilateral radiotherapy of the previous neck due to neoplasia in states T1-T2 and N0, N1 and N2a and, with 3 years of follow-up without recurrence.

Treatment is done with the same dose of 35x10E6 MSC in each gland with 2 millilitres suspension. The aim objectives of the study are: establish the changes in the xerostomia characteristics and discomfort degree, by means of questionnaires addressed to the physician and subject of study_OHIP-14-sp and EVA score_, determine the volume of submaxillary saliva without stimulation and with stimulation by sialometry, detect changes in volume, vascularization and fibrosis of submaxillary glands based on magnetic resonance imaging with contrast and, detect changes of submaxillary gland functionalism based on Gammagraphy, detected by a reduction of salivation and hyposalivation, evaluated by an examination, flow rate or whole unstimulated saliva in the range of $0.05-0.20 \mathrm{ml} / \mathrm{min}$ and, with a Grade 1-3 xerostomia as assessed by the grading scale.

We are currently finalizing the inclusion of patients in the study and are monitoring those we have already treated. The first data we are collecting from treated patients are very positive and promising for the future of patients with xerostomia. In addition, are expected a long-term effects of cell therapy due to epigenetic changes in receptor tissue cells [15] would facilitate the maintenance of the cell treatment effect. We believe that this therapy could be represent a new paradigm treatment for xerostomia.

\section{Conflict of interest}

The authors do not have any conflict of interest and not have received any subsidy to carry out the work.

${ }^{\star}$ Correspondence to: Joan Rius Tarruella, Institut de Teràpia Regenerativa Tissular (ITRT), Centro Médico Teknon Barcelona (Grupo Quirón Salud), Calle Vilana, 1208022 Barcelona, Spain, Tel: +34 932906042; E-mail: publicaciones@itrt.es

Received: June 10, 2019; Accepted: June 18, 2019; Published: June 25, 2019 


\section{References}

1. Dawes C (1987) Physiological factors affecting salivary flow rate, oral sugar clearance, and the sensation of dry mouth in man. J Dent Res 66: 648-653. [Crossref]

2. Vissink A, Jansma J, Spijkervet FKL, Burlage FR, Coppes RP (2003) Oral sequelae of head and neck radiotherapy. Crit Rev Oral Biol Med 14: 199-212. [Crossref]

3. Bralic M, Muhvic-Urek M, Stemberga V, Golemac M, Jurkovic S, et al. (2005) Cell death and cell proliferation in mouse submandibular gland during early post- irradiation phase. Acta Med Okayama 59: 153. [Crossref]

4. Deasy JO, Moiseenko V, Marks L, Chao KSC, Nam J, et al. (2010) Radiotherapy DoseVolume Effects on Salivary Gland Function. Int J Radiat Oncol Biol Phys 76. [Crossref]

5. Murdoch-Kinch CA, Kim HM, Vineberg KA, Ship JA, Eisbruch A (2008) Dose-Effect Relationships for the Submandibular Salivary Glands and Implications for Their Sparing by Intensity Modulated Radiotherapy. Int J Radiat Oncol Biol Phys 72: 373382. [Crossref]

6. Cotrim AP, Hyodo F, Matsumoto KI, Sowers AL, Cook JA, et al. (2007) Differential radiation protection of salivary glands versus tumor by tempol with accompanying tissue assessment of tempol by magnetic resonance imaging. Clin Cancer Res 13: 4928-4933. [Crossref]

7. van Luijk P, Pringle S, Deasy JO, Moiseenko VV, Faber H, et al. (2015) Sparing the region of the salivary gland containing stem cells preserves saliva production after radiotherapy for head and neck cancer. Sci Transl Med 7: 305ra147. [Crossref]

8. Lajer C, Buchwald C, Nauntofte B, Specht L, Bardow A, et al. (2009) Erosive potential of saliva stimulating tablets with and without fluoride in irradiated head and neck cancer patients. Radiother Oncol 93: 534-538. [Crossref]
9. Jensen DH, Oliveri RS, Trojahn Kølle S-F, Fischer-Nielsen A, Specht L, et al. (2014) Mesenchymal stem cell therapy for salivary gland dysfunction and xerostomia: a systematic review of preclinical studies. Oral Surg Oral Med Oral Pathol Oral Radiol 117: 335-342.e1. [Crossref]

10. Grønjøj Ch, Jensen DH, Vester-Glowinski P, Jensen SB, Bardow A, Oliveri RS, et al. (2018) Safety and Efficacy of Autologous Tissue-derived Mesenchymal Stem Cells for Radiation-Induced Xerostomia: A Randomized, Placebo-Controlled Phase I/II Trial (MESRIX). Int J Radiat Oncol Biol Phys 1: 581-592. [Crossref]

11. Orozco L, Munar A, Soler R, Alberca M, Huguet M, et al. (2013) Treatment of knee osteoarthritis with autologous mesenchymal stem cells: a pilot study. Transplantation 95: 1535-1541. [Crossref]

12. Orozco L, Soler R, Morera C, Alberca M, Sánchez A, et al. (2011) Intervertebral Disc Repair by Autologous Mesenchymal Bone Marrow Cells: A Pilot Study. Transplantation 92: 822-828. [Crossref]

13. Soler R, Orozco L, Munar A, Huguet M, López R, et al. (2016) Final results of a phase I-II trial using ex vivo expanded autologous Mesenchymal Stromal Cells for the treatment of osteoarthritis of the knee confirming safety and suggesting cartilage regeneration. Knee 23: 647-654. [Crossref]

14. Vega A, Martín-Ferrero MA, Del Canto F, Alberca M, García V, et al. (2015) Treatment of knee osteoarthritis with allogeneic bone marrow mesenchymal stem cells: a randomized controlled trial. Transplantation 99(8):1681-90. [Crossref]

15. Ng KS, Kuncewicz TM, Karp JM (2015) Beyond Hit-and-Run: Stem Cells Leave a Lasting Memory. Cell Metab 22: 541-543. [Crossref]

Copyright: (C2019 Robert SR. This is an open-access article distributed under the terms of the Creative Commons Attribution License, which permits unrestricted use, distribution, and reproduction in any medium, provided the original author and source are credited. 